\title{
INTEGRATED MEDICAL PARASITOLOGY IN UNDERGRADUATE COMPETENCY BASED CURRICULUM
}

\section{By}

\author{
HEBA E. ABDEL AATY ${ }^{1 *}$ and SAFINAZ ADEL ELHABASHY ${ }^{2}$
}

Department of Parasitology, College of Medicine, Misr University for Science and Technology, $6^{\text {th }}$ October City and Department of Parasitology ${ }^{1}$, and Department of Pediatrics ${ }^{2}$, Faculty of Medicine, Ain Shams University, Cairo 11566, Egypt ( ${ }^{*}$ Correspondence: drheba_abdelatty@med.asu.edu.eg)

\section{Abstract}

The paradigm shift of undergraduate medical education in Egypt to competency based and the change role of basic medical sciences from knowledge acquisition in disciplines to contextual learning related to future graduate career. The present work represents a prototype how parasitology and other basic sciences are incorporated with paediatrics as early as the second year of study, although an in-depth paediatrics courses will be in the clerkship phase. A holistic approach for the clinical presentation "Watery diarrhoea in 6 years old immunocompromised child under chemotherapy in a hospital ward" is represented in relation to different relevant learning theories in team based and task based learning strategies for promoting authentic learning since early in undergraduate medical curriculum.

Keywords: Basic medical sciences, Curriculum, competency, Integrated, Learning theories, Medical education, Paediatrics, Parasitology, Task based, Team based.

\section{Introduction}

Long ago, health professions education has focused more on outcome competencies, "what the graduate is able to do rather than how much s/he knows". This goal influenced the move towards designing and implementing competency based curricula (Harden, 1999). Nowadays, in Egyptian Medical Education, there is a paradigm shift to competency based education (CBME); its core limit is the National Academic Reference Standards (NARS, 2017) \& Egyptian National Qualifications Framework (NQF, 2017). Therefore, College of Medicine, Misr University for Science and Technology (MUST) adopting the standards put the framework of its competency based integrated curriculum (Fig. 1). In CBME, emphasis has shifted towards outcomes, graduate capabilities at workplace, and learner-centeredness. With a focus on sustained evidence of professional competence, there is a call to change methods of teaching and assessment (Harold, 2013). The current trend is to use a blend of learning methods guided by the program competencies and outcomes (Hamdy, 2013).

The greatest challenges for implementing such program are change management and how to move from the comfort zone of the mind-set of disciplines, which is the exten- sive role of capacity building not only for the instructors, but also to the society and the learners themselves coming from different learning environment in their high school education. Other challenge that can't be ignored is that students are multinational mostly from Egypt, Middle East and Africa. The creeping globalization with the entire world constituting one market for the medical graduates is a responsibility.

As a snapshot on year $2,2^{\text {nd }}$ term under the theme of "systems in practice and clinical reasoning, digestive and hepatobiliary systems" (Fig. 2); the rationale beyond choosing this course of study in the pre-clerkship phase is to clarify how parasitology and clinical sciences can be integrated when parasitology put into application in a clinical context like "diarrhea in cancer patient", which can be revisited again under oncology in the clerkship phase (vice versa); what can be called contextual learning in a spiral approach (Hamdy, 2013). This trend necessitates the implementation of authentic learning strategies with underpinning learning theories, using small groups, student centred learning and early introduction of clinical sciences. Authentic learning cuts across disciplines and brings students into meaningful contact with the real world and patients (Hamdy, 2013). 
So, the work aimed to present a prototype how integration of parasitology with other disciplines could be, which conserves the importance of basic sciences in medical curricula but with relevance to different learning theories and strategies related to competency based medical curricula.

\section{Methods and Plans}

A blend of inductive strategies; Team based learning (TBL) (Haidet et al, 2002; Parmelee et al, 2012) and task based learning (Harden et al, 1996) was adopted as proposed:

Module: Digestive \& hepatobiliary systems
Clinical presentation: Watery diarrhoea in 6 years old immunocompromised child under chemotherapy in a hospital ward.

Target learners: $2^{\text {nd }}$ year medical students participating departments: Parasitology, Mirobiology, Physiology, Pathology, Pharmacology and Paediatrics.

Duration: One week activities

A case scenario as a learning stimulus will be designed by the subject matter experts including a case of cryptosporidiosis in a hospitalized leukaemic child under chemotherapy with signs of dehydration \& collapse shown on a video of a real case (e.g. from paediatrics ward after consent).

Table 1: Alignment of learning needs with instruction and learning theories.

\begin{tabular}{|c|c|c|}
\hline Learning needs & Instruction & References \\
\hline $\begin{array}{l}\text { 1- List causes of watery diarrhoea in immunocompromised child } \\
\text { with special emphasis on opportunistic Cryptosporidium species } \\
\text { as a common cause. } \\
\text { 2- Discuss nosocomial sources of infection \& infection control. } \\
\text { 3- Interpret Cryptosporidium parasite host relationship into } \\
\text { pathogenesis \& disease management. }\end{array}$ & $\begin{array}{l}\text { TBL } 11 / 2 \text { hour session; all students in } \\
\text { lecture hall divided into groups of ten with } \\
\text { one knowledgeable instructor (Portfolio) }\end{array}$ & $\begin{array}{l}\text { (Schmidt, 1993). } \\
\text { (Bandura, 1977; } \\
\text { Schon, 1983). } \\
\text { (Vygotsky, 1978) } \\
\text { (Mayer, 2004) }\end{array}$ \\
\hline $\begin{array}{l}\text { 4- Prepare acid fast stool smear for cryptosporidiosis diagnosis o. } \\
\text { 5- Apply infection control and safety measures }\end{array}$ & $\begin{array}{l}\text { Task based learning } 2 \text { hours' lab session for } \\
10 \text { classes/ week (worksheet \& microscopic } \\
\text { picture for the prepared smear; portfolio) }\end{array}$ & \multirow{3}{*}{$\begin{array}{l}\text { (Taylor \& Hamdy, } \\
\text { 2013) } \\
\text { (Dewey, 1938; } \\
\text { Kolb, 1984) } \\
\text { (Bandura, 1977; } \\
\text { Schon, 1983). } \\
\text { (Vygotsky, 1978). } \\
\text { (Andersen, 1993) }\end{array}$} \\
\hline $\begin{array}{l}\text { 6- Diagnose different dehydration degrees } \\
\text { 7- Assist in cup and spoon rehydration } \\
\text { 8- Calculate I.V. fluids needed to correct dehydration }\end{array}$ & $\begin{array}{l}\text { Task based learning } 2 \text { nights shift } \\
\text { attachment to train residents in paediatrics } \\
\text { emergency } \\
\text { (journals \& reflective portfolio) }\end{array}$ & \\
\hline 9- Insert peripheral and central I.V. line & $\begin{array}{l}\text { Task based learning in } 2 \text { skill labs/week } \\
\text { (logbook \& report) }\end{array}$ & \\
\hline
\end{tabular}

Students should be prepared by: Pre-readings (resources from suitable books and online resources provided by the staff and self-learning online quizzes with feedback). In TBL session, students will be subjected to MCQ I-RAT \& G-RAT allowing intragroup and inter-groups learning and finally asked to reflect on the pre-given scenario and video. Then the students will be assigned certain tasks (observable behaviour and feedback) which are: Skill lab: 1-Prepare for the skill lab by watching assigned video of how to insert different I.V. lines. 2- Use their study guide (SOP) to insert different IV line in the skill lab first under supervision and then peer to peer learning to be repeated for 15 times to be competent and reported in their log-book.

Parasitology lab: Prepare faecal smear stained by modified Zeihl Neelson to diagnose Cryptosporidium oocyst using lab manual
(SOP) and first attended by a demonstrator for groups of five to be repeated 5 times.

Paediatrics hospital: 1- Attach to trained residents while managing cases of dehydration for 2 night shifts (recorded by the student in the reflective portfolio). 2- Assist in cup and spoon rehydration.

Effective feedback (formative and summative) (Jessica, 2007): It is given during and by the end of the session which is mandatory. Formative feedback helps the instructor and student to remediate the deficiencies in competency acquisition.

\section{Reflection and Discussion}

Competency based curricula are better implemented when there is a proper alignment between the outcomes and instructional methods. From a Cognitive perspective, authentic learning promotes critical thinking, reasoning process and mechanisms of processing and retrieving new information (Dol- 
mans et al, 2002). The concept of learning scaffold and zone of proximal development (Vygotsky, 1978) are good representations of teacher interaction with the students. The current trend is to use a blend of learning methods guided by the program competencies (Hamdy, 2013). Team based and task based learning strategies derive from aspects of contemporary learning theories. The learning stimulus could be a case scenario, a task or a real patient. The reaction behaviour of the learner to the stimulus is influenced by the context; more important is for the beOhaviour to become a habit (Schmidt, 1993).

TBL enhances the ability of work effecttively in a team. It is a model of "guided discovery learning" (Mayer, 2004). TBL allows large number of students to learn in small groups in one classroom with one faculty who is a subject matter expert and his role changes from information giver to a planner and facilitator of learning. Students are active learners before, during and after the class session. The new buzz term for TBL; the flipped classroom can be seen to spread in higher education (Hamdy, 2015). Social constructivism theory (Schon, 1983) constitutes the main framework of TBL. Social theories of learning emphasize the importance of creating a community of learners. At present, social media and electronic communication are good examples of this principle (Hamdy, 2013). The social perspective helps students and teachers' reflection on content, process and learning experience (Bandura, 1977). Students should be trained on how to record their experience in reflective portfolio. Teachers should regularly evaluate the reflective portfolio giving constructive feedback.

Task based learning has been described as practice based learning (Andersen, 1993). The tasks can represent the outcome competencies of a program (Harden, 1997). For each task, there is a list of objectives students should work to achieve. It is a clear example of experiential learning in which the learning cycle is divided into 4 stages: active experimentation, abstract conceptualization, concrete experience, and reflective observation (Kolb, 1984). After each session, each student reflects on experience by answering five questions "what I have observed, what did I do, what did I learn, what I still do not understand, what I am going to do to fulfil my gaps". Task and context constitutes the heart of a three-way relationship between teachers, learners and learning outcomes. True integration happens in the mind of the learner. Students could articulate different concepts and skills related to the task; basic sciences, decision making, clinical skills, communication skills, ethics etc. The same task can be presented at different phases of the curriculum and in different learning and practice enviromments such as skill labs, hospitals and clinics. Attention to the logistics of implementation, limited number of students, training clinical teachers and evaluation of session and faculty are important issues to be considered to ensure its success (Hamdy, 2013).

\section{Conclusion}

In CBME, there is no separate islands of disciplines, there is no single proper method or theory of learning in medical education, but the point is that how to instruct your graduate to fit in the workplace at graduation. To tailor suitable learning episodes, it is the matter of inputs including place and space of learning, human resources including students and even patients, choosing the suitable learning process to achieve the desired outcome; putting in mind that learning is accelerated, when it is in a context or situation, especially those similar to real life. No more bottle or spoon feeding for the $21^{\text {st }}$ Century physicians. They are adult learners who are already motivated to learn.

\section{References}

Anderson, JR, 1993: Problem solving and learning. Am. Psychol. 48, 1:35-44.

Bandura, A, 1977: Social Learning Theory. New York: General Learning Press.

Dewey, J, 1938: Experience and Education. New York: Simon and Schuster. 
Dolmans, DH, Gijselaers, WH, Moust, JH, de Grave, WS, Wolfhagen, JH, et al, 2002: Trends in research on the tutor in problem-based learning: Conclusions and Implications for educational practice and research. Med. Teacher 24, 2: 173-80.

Haidet, P, O'Malley, KJ, Richards, B, 2002: An initial experience with team learning in medical education. Acad. Med. 77:40-4.

Hamdy, H, 2013: Authentic learning in Health Professions Education: Problem Based Learning, Team Based Learning; Task Based Learning: Case Based Learning and the Blend: International Handbook of Medical Education.

Hamdy, H, 2015: One size does not fit all: B1ended learning strategies in Medical education. www.sciencedirect.com Health Professions Education 1:65-6.

Harden, RM, Laidlaw Jennifer M, Ker Jean, Mitchell, H, 1996: Task-based learning: An educational strategy for undergraduate, post-graduate and continuing medical education. AMEE Med. Educ. booklet No 7; Med. Teacher 18:713, 91-8.

Harold, GJ, 2013: Programmatic assessment of competency-based workplace learning: when theory meets practice. BMC Med. Educ. 13, 123:
1474

Jessica, L, Nadine, TK, Susan, MC, Nancy, H, Sonya, E, 2007: Providing feedback. Am. J. Obst. Gyn. 5:08-13

Kolb, DA, 1984: Experiential Learning. Englewood Cliffs, New Jersey: Prentice Hall.

Mayer, RE, 2004: Should there be three-strike rule against pure discovery learning? a case for guide methods of instruction. Am. Psychol. 59, 1:14-9.

Parmelee, D, Michaelsen, LK, Cook, S, Hudes, PD, 2012: Team based learning: a practical guide: AMEE guide No 65. Med. Teacher 34, 5: 275-87

Schmidt, HG, 1993: Foundations of problembased learning: Some explanatory notes. Med. Educ. 27, 5:422-32.

Schon, DA, 1983: Educating the Reflective Practitioner. San Francisco: Jossey-Bass limited, Taylor, DC, Hamdy, H, 2013: Adult Learning Theories: Implications for learning in medical education: AMEE Guide No 83. Med Teacher Available from informahealthcare.com by University of Sharjah on 10/07/13

Vygotsky, L, 1978: Mind in Society: The Development of Higher Psychological Processes. Cambridge, MA: Harvard University Press.

\section{Explanation of figures}

Fig. 1: Program framework at College of Medicine, MUST, Fig. 2: Curricular map of pre-clership phase, College of Medicine, MUST

PHASE I: FUNDAMENTALS OF MEDICAL STUDY PHASE
- Year 1: Fundamentals of: human body, human behaviour and research
PHASE II: PRECLERKSHIP PHASE
- Year 2: Systems in practice and clinical reasoning
- Year 3: Transition to community and hospital based practice
PHASE III: CLERKSHIP PHASE ( 84 Cr.Hrs)
- Year 4 \& 5: Clinical clerkship and professionalism
F. 1

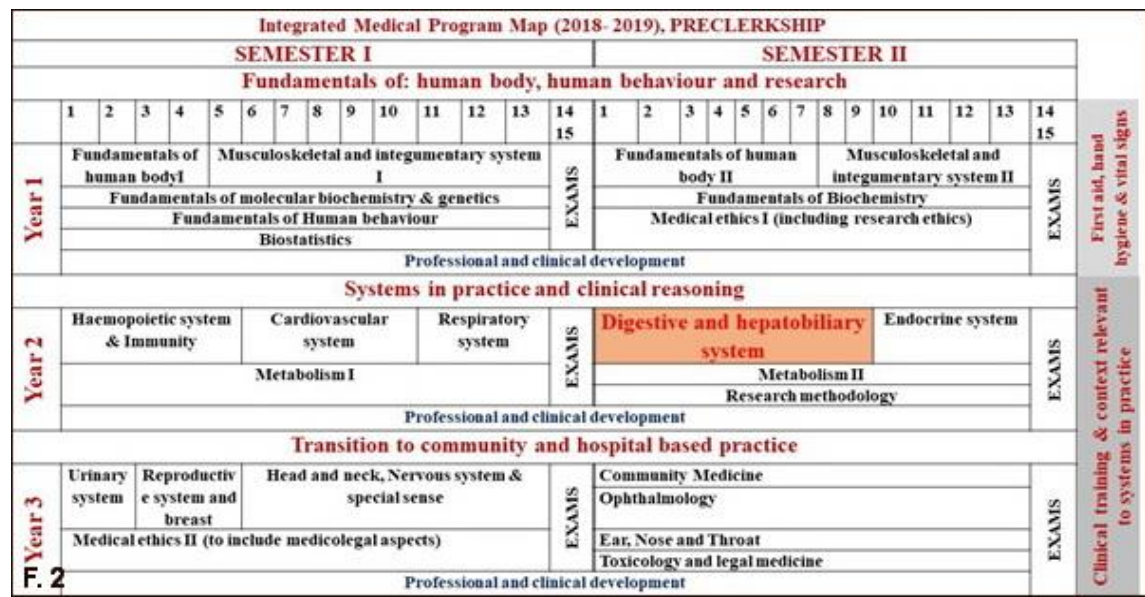

